Indian J Anim Health (2021), 60(1) : 23-30

DOI:10.36062/ijah.60.1.2021.23-30

Research Article

\title{
Circadian changes in plasma major and trace minerals of Black Bengal goats during different seasons in hot-humid tropics of India
}

\author{
S. C. Reddy ${ }^{1}$, P. R. Ghosh ${ }^{1}$, P. K. Das ${ }^{1}$, J. Mukherjee ${ }^{1}$, A. K. Patra ${ }^{2}$, S. Naskar ${ }^{3}$, B. C. Das ${ }^{4}$ and \\ D. Banerjee ${ }^{1 *}$
}

${ }^{1}$ Department of Veterinary Physiology, West Bengal University of Animal and Fishery Sciences, Kolkata 700 037, West Bengal, India; ${ }^{2}$ Department of Animal Nutrition, West Bengal University of Animal and Fishery Sciences, Kolkata 700 037, West Bengal, India; ${ }^{3}$ Indian Council of Agriculture Research- Indian Veterinary Research Institute (Eastern Regional Station), Kolkata 700 037, West Bengal, India; ${ }^{4}$ Indian Council of Agriculture Research- National Research Centre on Pig, Rani, Guwahati 781 131, Assam, India

\begin{abstract}
A study was conducted to explore the circadian changes of plasma major and trace minerals in Black Bengal goats during the summer, winter, and spring seasons. Six healthy un-castrated Black Bengal bucks, aged between 0.8 to 1.5 years, were selected for the present study. The blood samples $(5 \mathrm{~mL} / \mathrm{animal})$ were collected four times a day at six-hour intervals for three consecutive days in each season (summer, winter and spring). Plasma major minerals (sodium, potassium and magnesium) and trace minerals (copper, zinc and iron) were analyzed by atomic absorption spectrophotometer. The plasma sodium and potassium concentrations were significantly $(\mathrm{P}<0.001)$ lower during summer, followed by spring and winter. In all the seasons, plasma sodium showed peak levels in the afternoon (3:00 PM). No circadian pattern of plasma magnesium concentration was noted. The plasma copper concentration alteration was seasonally dependent with lower values at 3:00 AM in winter and spring and at 9:00 PM in summer. Plasma concentrations of zinc and iron did not alter $(P>0.05)$ with season or hours. These findings revealed a circadian rhythm in plasma major mineral concentrations of Black Bengal goats.
\end{abstract}

Key words: Black Bengal goat, Circadian rhythm, Plasma major minerals, Trace minerals

\section{INTRODUCTION}

Goats are considered as the "poor man's cow" due to their immense economic importance (MacHugh and Bradley, 2001) among the small and marginal farmers, including landless agricultural laborers (Rekib, 1998), particularly in developing countries. Among different goat breeds in India, Black Bengal goat is a wellrenowned type known for delicious meat and superior hide quality (Amin et al., 2001) and its high adaptability and prolificacy (Husain et al., 1996). Thus, goat enterprise is a promising sector for entrepreneurship and socio-economic development (Husain et al., 1996). The role of different minerals in livestock growth and production performance was established for a long time (Kincaid, 1988), and their deficiencies lead to growth and production impairment. Along with other physio-biochemical parameters, plasma electrolyte concentration followed a definite circadian pattern in rats (Fang et al., 2000), mice (Gumz et al., 2009), squirrel and monkey (Nikolaeva et al., 2012), cattle (Banerjee and Ashutosh, 2011) and human (Schmidt et al., 2015). However, very scanty literature is available in small ruminants for the circadian changes of plasma major and trace minerals. Therefore, the present investigation aimed to understand the circadian rhythm of plasma major and trace minerals of Black Bengal goats reared in a semi-intensive system. An attempt was also made to determine whether this circadian pattern altered during different seasons, which might help in mineral

*Corresponding Author 
supplements during the demand to sustain production and avoid deficiency disorders.

\section{MATERIALS AND METHODS}

The experiment was performed following the guidelines of the regional Animal Ethics Committee and the rules for experimental animals of the University. The study was carried out at the goat farm of ICAR-Indian Veterinary Research Institute, Eastern regional station situated at Kalyani, Nadia district of West Bengal, India. The farm is located at $14 \mathrm{~m}$ above sea level (23.4 North and $88.57^{\circ}$ East). All the experimental metrological variables (ambient temperature, relative humidity, dry bulb temperature, and wet bulb temperature) at the location were recorded throughout the experimental period (Fig. 1). Temperature Humidity Index (THI) was calculated from dry and wet bulb temperature using the following formula (Johnson et al., 1963).

$\mathrm{THI}=0.72(\mathrm{Dbt}+\mathrm{Wbt})+40.6$

Where, Dbt $=$ dry bulb temperature in ${ }^{\circ} \mathrm{C}$, $\mathrm{Wbt}=$ wet bulb temperature in ${ }^{\circ} \mathrm{C}$

Six healthy un-castrated Black Bengal bucks of 0.8 to 1.5 years (average body weight of $9.5-10.5 \mathrm{~kg}$ ) were selected for the present study. All the animals were kept in dry, clean, well-ventilated sheds with concrete floors. Deworming was done as per standard protocol. Routine fecal examinations were carried out periodically to diagnose parasitic infestations during the entire course of the experimental study. The experimental animals were managed in an extensive system with free-range browsing during the entire day (8 AM to 5.30 PM) and provided shelter at night. No extra feed or concentrate was provided to the animals, except with clean and fresh drinking water ad libitum. The experimental work was conducted during three different phases that coincide with the three seasons of West Bengal, i.e., winter (mid-November to mid-February), spring (mid-February to mid-April), and summer (mid-April to mid-June). The blood samples (5 mL/animal) were collected in heparinized vacutainers at $6 \mathrm{~h}$ intervals on 3 consecutive days each season. Plasma was obtained from the blood samples after centrifugation at $3000 \mathrm{rpm}$ for 30 minutes. The concentrations of plasma major minerals $(\mathrm{Na}$, $\mathrm{K}$ and $\mathrm{Mg}$ ) and trace minerals $(\mathrm{Cu}, \mathrm{Zn}$ and $\mathrm{Fe}$ ) were determined by atomic absorption spectrophotometer (AAS, Model 3300, Thermo Fisher). Data were analyzed in a completely randomized design using the mixed model

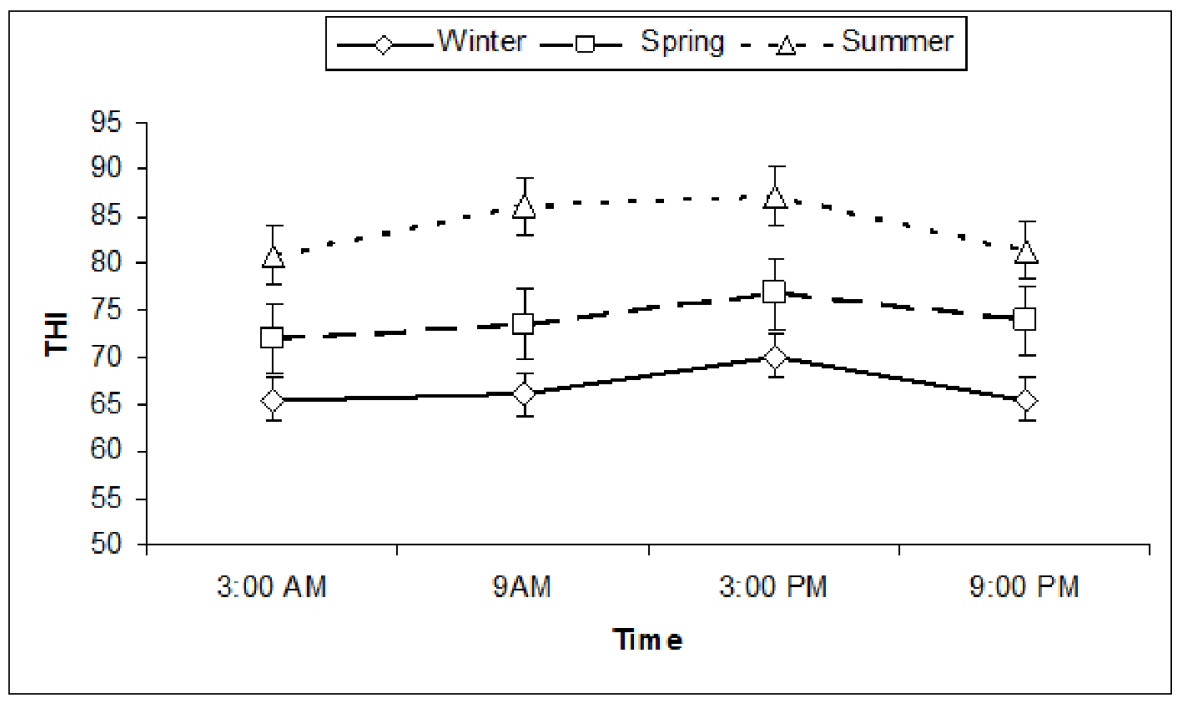

Fig. 1. Temperature humidity index (THI) of the experimental area during the study period (Values are expressed as mean \pm SEM) 
procedure of SAS (2001) with the model containing season, time, and interaction between season and time as main effects and animal as random effects. The time was used as the repeated measure with the animal as a subject. Compound symmetry (types) was selected as a covariance structure according to the best fit using Akaike Information Criterion. Probability values of $\mathrm{P}<0.05$ were declared as significant, and that of $0.05<\mathrm{P}<0.10$ as a trend. When the interaction between treatment and day was significant $(\mathrm{P}<0.05)$, the SLICE option in the LSMEANS statement was used to determine differences among the time at each season. Tukey's test was employed to differentiate the significant differences among the time.

\section{RESULTS \\ Plasma major minerals}

The plasma $\mathrm{Na}$ concentration of Black Bengal goats was significantly $(\mathrm{P}<0.001)$ lower during summer followed by spring and winter (Fig. 2A). Irrespective of seasons, the plasma $\mathrm{Na}$ concentration sharply increased from early morning (9:00 AM), reached a peak level in the afternoon (3:00 PM), and after that sharply declined till 9:00 PM.

Plasma $\mathrm{K}$ concentration varied significantly $(\mathrm{P}<0.001)$ during different seasons and different hours of the day (Fig. 2B). The plasma $\mathrm{K}$ concentration followed an exact opposite pattern to that of $\mathrm{Na}$. In all the seasons, plasma potassium concentration was highest in the morning (3.00 AM), which followed a sharp declining trend up to 3:00 PM and 9:00 PM.

There was a significant $(\mathrm{P}<0.001)$ variation in plasma magnesium concentration during different seasons with the highest value around winter followed by summer and spring; but, within a season, the circadian variation of plasma magnesium concentration was found non-significant $(\mathrm{P}>0.05)$ (Fig. 2C).

\section{Plasma trace minerals}

Plasma $\mathrm{Cu}$ varied significantly $(p<0.001)$ during different hours of the day in Black Bengal goats (Fig. 3A). The copper concentration exhibited different circadian patterns in different seasons. In winter and spring, lower values were found at 3:00 PM, slightly increased by 9:00 PM, followed by a sharp increase by 3:00 AM, and then decreased by 9:00 AM. But, in summer, the lowest value was found at 9:00 PM, followed by an increasing trend till afternoon 3:00 PM.

The plasma $\mathrm{Zn}$ concentration showed no significant variations in different seasons and different hours of the day (Fig. 3B). The Zn concentration did not follow any circadian pattern. The lower values were found at 3:00 AM during spring and summer and increased by 9:00 AM and decreased by 3:00 PM and levels were almost the same till 9:00 PM. But, in winter, the lower values were found at 9:00 $\mathrm{AM}$, and levels were almost the same till 3:00 PM and increased by 9:00 PM and decreased by 3:00 AM.

No significant variations were observed in blood plasma $\mathrm{Fe}$ concentration variations during different hours of the day and different seasons. Like plasma $\mathrm{Zn}$ concentration, the $\mathrm{Fe}$ concentration did not follow any circadian pattern (Fig. 3C).

\section{DISCUSSION}

In our study, plasma $\mathrm{Na}$ and $\mathrm{K}$ concentrations were as per Holtenius (1990) reports, but slightly lower than Madan et al. (2020). In the present investigation, both $\mathrm{Na}$ and $\mathrm{K}$ concentration showed circadian rhythmicity where plasma $\mathrm{Na}$ concentration was lowest during early morning and increased to pick levels by afternoon, while plasma $\mathrm{K}$ concentration was found reverse to $\mathrm{Na}$ concentration. Circadian alterations in plasma $\mathrm{Na}$ and $\mathrm{K}$ concentrations were demonstrated in several mammals. The rhythmic oscillations in the plasma sodium and potassium concentrations depicted in our study were corroborated with the earlier reports in rats (Fang et al., 2000) and humans (Schmidt et al., 2015). The circadian variations in plasma $\mathrm{Na}$ and $\mathrm{K}$ concentration were well synchronized with the circadian variations in the renal clearance of $\mathrm{Na}$ and $\mathrm{K}$ by the kidney as reported 

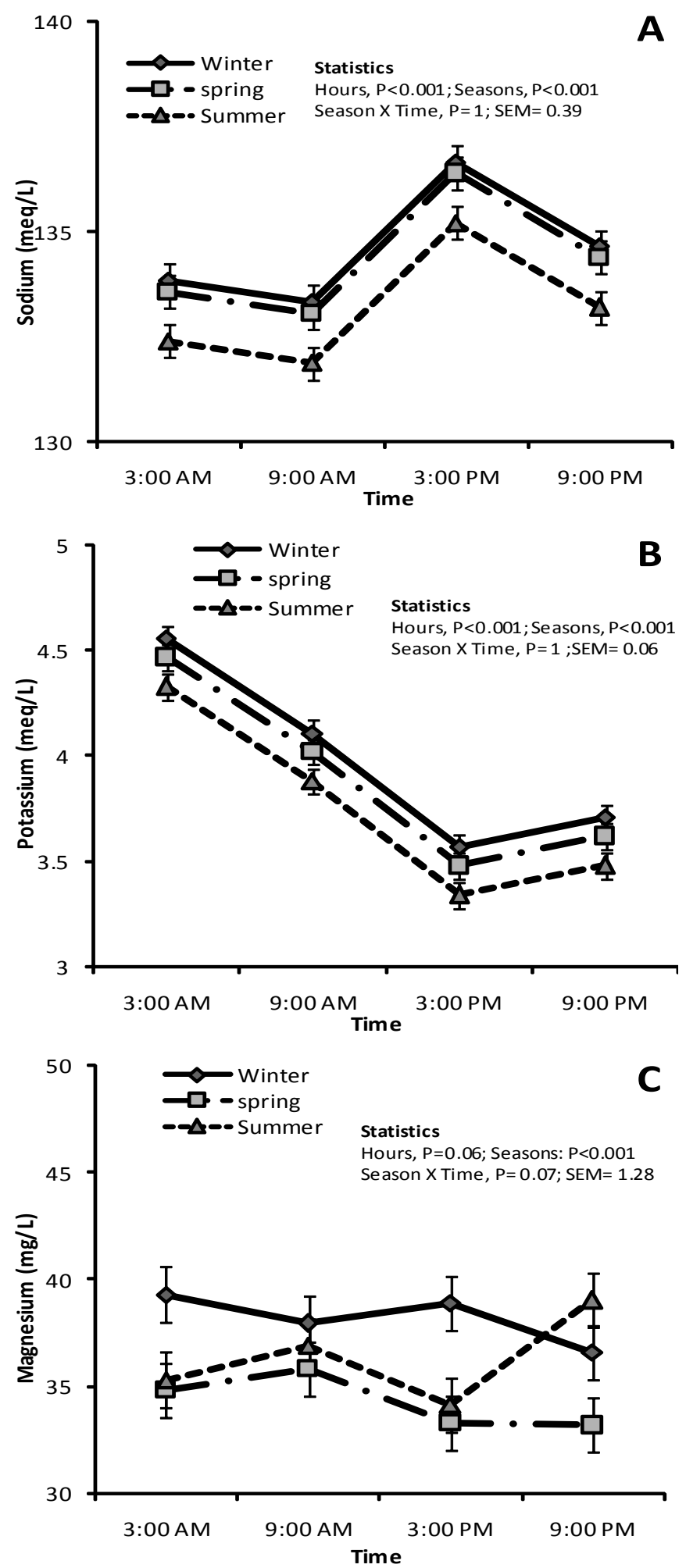

Fig. 2. Circadian changes of plasma major minerals of Black Bengal goats during different seasons (Values are expressed as mean \pm SEM). (A) Circadian changes of plasma sodium $(\mathrm{meq} / \mathrm{L})$; (B) Circadian changes of plasma potassium (meq/L); (C) Circadian changes of plasma magnesium $(\mathrm{mg} / \mathrm{L})$ 
Circadian changes of plasma major and trace minerals of goats
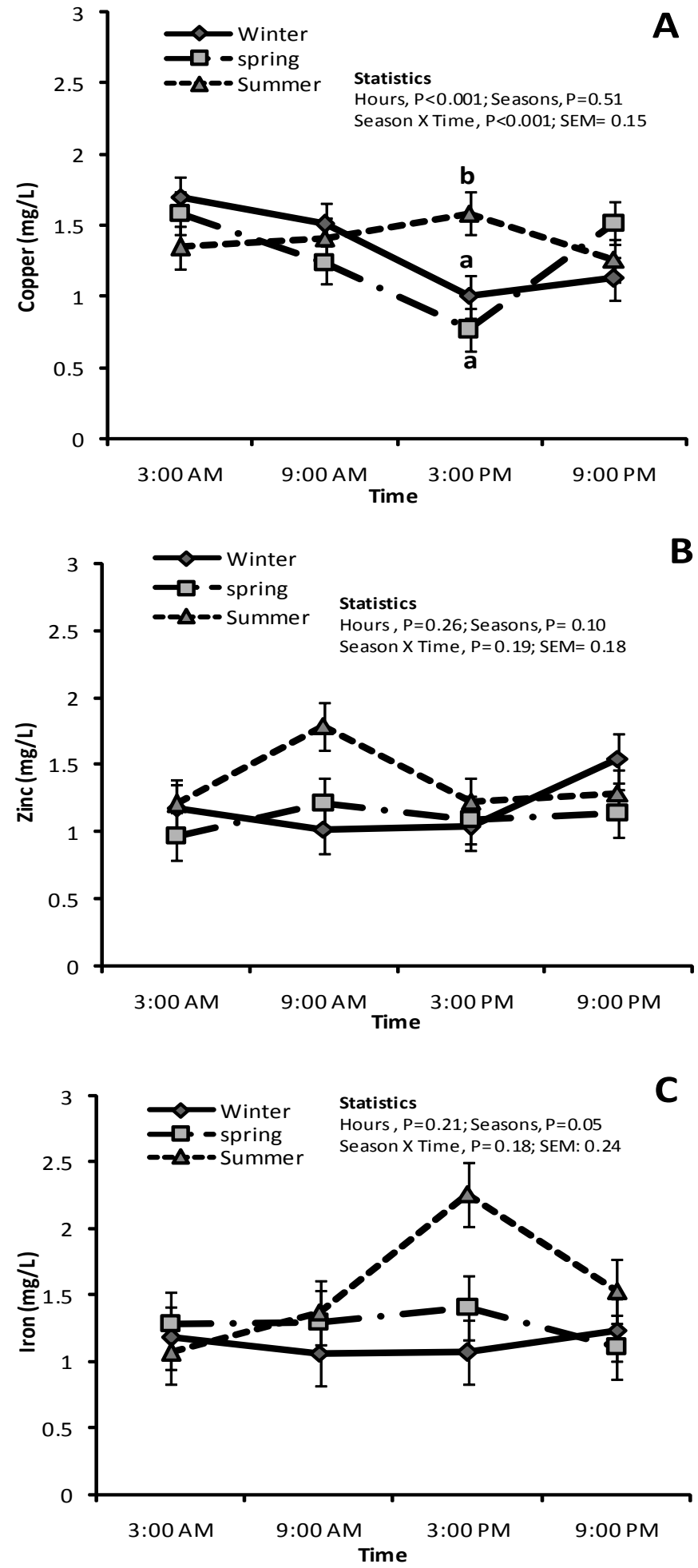

Fig. 3. Circadian changes of plasma trace minerals of Black Bengal goats during different seasons (Values are expressed as mean \pm SEM); (A) Circadian changes of plasma copper $(\mathrm{mg} / \mathrm{L}$ ) [Different letters $(a, b)$ within a time point show significant $(P<0.05)$ difference among the seasons]; (B) Circadian changes of plasma zinc (mg/L); (C) Circadian changes of plasma iron $(\mathbf{m g} / \mathrm{L})$ 
in humans (Koopman et al., 1991; Solocinski and Gumz, 2015) and rats (Luke et al., 1990) with some probable involvement of some renal paracrine factors controlling the diurnal pattern (Zhang and Pollock, 2020).

In the present investigation, goats maintained the circadian rhythmicity of plasma $\mathrm{Na}$ and $\mathrm{K}$ even during different seasons. However, the concentration of plasma $\mathrm{Na}$ and $\mathrm{K}$ was highest in the winter and lowest in summer, and supported by earlier reports of Sivakumar et al. (2010) in goats, and Banerjee and Ashutosh (2011) in cattle. Decreased plasma $\mathrm{Na}$ and $\mathrm{K}$ levels during summer in the present investigation may be due to decreased retention and loss in sweating (Singh et al., 2001) and increased urinary $\mathrm{Na}$ excretion and total urinary output during heat stress (El-Nouty et al., 1980). The study found a significantly higher level of $\mathrm{Mg}$ in goats during winter, following the findings of Abdelrahman et al. (1998) in cattle, contrary to Dar et al. (2014) in sheep. Mohammed et al. (2017) also reported higher Mg concentration during dry seasons in goats.

The concentrations of plasma $\mathrm{Cu}, \mathrm{Fe}$, and $\mathrm{Zn}$ were per the earlier reports of Haldar et al. (2014) in Black Bengal goats; but were slightly higher than the reports of Bhausaheb et al. (2014) in non-descriptive goats. In the present investigation, plasma copper concentration showed significant circadian variations in $\mathrm{Cu}$ and $\mathrm{Zn}$, corroborated by earlier reports in humans (Hetland and Brubakk, 1973;

\section{REFERENCES}

Abdelrahman MM, Kincaid RL and Elzubeir EA, 1998. Mineral deficiencies in grazing dairy cattle in Kordofan and Darfur regions in Western Sudan. Trop Anim Health Prod, 30(2): 123-135, doi: 10.1023/a:1005051902115

Amin MR, Husain SS and Islam ABMM, 2001. Reproductive peculiarities and litter weight in different genetic groups of Black Bengal does. Asian-Australas J Anim Sci, 14(3): 297-301

Banerjee D and Ashutosh, 2011. Circadian changes in physiological responses and blood ionized sodium and potassium concentrations under thermal exposure in Tharparkar and Karan Fries
Markowitz et al., 1985; Yokoyama et al., 2000), whereas no significant circadian variations observed in $\mathrm{Fe}$ concentration in this study. In contrast, Casale et al. (1981) reported circadian variations in plasma iron concentration in humans.

In the present investigation, there was a non-significant rise in plasma $\mathrm{Cu}$ concentration during winter, corroborating the reports in goats (Bhattacharyya et al., 1995; Mohammadpour et al., 2017) and sheep (Dar et al., 2014). In this study, no seasonal variations were observed in plasma $\mathrm{Zn}$, and $\mathrm{Fe}$ concentration in goats, whereas Bhausaheb et al. (2014) reported lower plasma $\mathrm{Zn}$ content in goats during summer than in the rainy season. Bhattacharyya et al. (1995) reported higher plasma $\mathrm{Fe}$ concentrations of blood in goats during the winter season than in summer.

The data obtained from the study indicated that Black Bengal goats could maintain plasma levels of major and trace minerals within the physiological limits even during seasonal variations. A definite circadian pattern of plasma $\mathrm{Na}$ and $\mathrm{K}$ has been recorded. Knowing the levels of different major and trace minerals during different seasons may help in formulating mineral supplements during different seasons to avoid deficiency disorders.

Conflict of interest: Authors have no conflict of interest in this study.

heifers. Biol Rhythm Res, 42(2): 131-139, doi: 10.1080/09291011003729411

Bhattacharyya BN, Talukdar SC and Baruah RN, 1995. Studies on circulatory levels of trace minerals at different reproductive status in goat. Indian $\mathbf{J}$ Anim Reprod, 16(2): 96 - 98

Bhausaheb KS, Tiwari SP, Sahu T, Naik SK and Gendley MK, 2014. Trace mineral status of soil, feed and animal in Chhattisgarh state (India). Int J Adv Res, 2(5): 443-448

Casale G, Migliavacca A, Bonora C, Zurita IE and de Nicola P, 1981. Circadian rhythm of plasma iron, total iron binding capacity and serum ferritin in 
arteriosclerotic aged patients. Age Ageing, 10(2): 115-118, doi: 10.1093/ageing/10.2.115

Dar AA, Jadhav RK, Dimri U, Khan AA, Khan HM et al., 2014. Effects of physiological status and seasonal variation on plasma mineral profile of sheep in Kashmir valley. Sci Res Essays, 9(4): 69-76, doi: 10.5897/SRE2013.5694

El-Nouty FD, Elbanna IM, Davis TP and Johnson HD, 1980. Aldosterone and ADH response to heat and dehydration in cattle. J Appl Physiol, 48(2): 249-255, doi: 10.1152/jappl.1980.48.2.249

Fang Z, Carlson SH, Peng N and Wyss JM, 2000. Circadian rhythm of plasma sodium is disrupted in spontaneously hypertensive rats fed a high$\mathrm{NaCl}$ diet. Am J Physiol Regul Integr Comp Physiol, 278(6): R1490-R1495, doi: 10.1152/ ajpregu.2000.278.6.R1490

Gumz ML, Stow LR, Lynch IJ, Greenlee MM, Rudin A et al., 2009. The circadian clock protein period1 regulates expression of the renal epithelial sodium channel in mice. J Clin Invest, 119(8): 2423-2434, doi: 10.1172/JCI36908

Haldar A, Pal SK, Datta M, Majumdar D and Prakash BS, 2014. Plasma micronutrients status and gonadotrophin hormone profiles during peripubertal period in female Black Bengal goat. Indian J Anim Sci, 84 (12): 1270-1275

Hetland O and Brubakk E, 1973. Diurnal variation in serum zinc concentration. Scand J Clin Lab Invest, 32(3): 225-226, doi: 10.3109/ 00365517309082463

Holtenius K, 1990. Plasma electrolyte concentration in food-deprived goats orally supplemented with potassium chloride. Br J Nutr, 64(1): 211218, doi: 10.1079/BJN19900022

Husain SS, Horst P and Islam ABMM, 1996. Study on the growth performance of Black Bengal goat in different periods. Small Ruminant Res, 21(3): 165-171, doi: 10.1016/0921-4488(95)00832-2

Johnson HD, Ragsdale AC, Berry IL and Shanklin MD, 1963. Temperature-humidity effects including influence of acclimation in feed and water consumption of Holstein cattle. Missouri Agril Exp Station Res Bul, No. 846

Kincaid RL, 1988. Macro elements for ruminants. In: D.C. Church (edn.), Ruminant Animal Digestive Physiology and Nutrition, (Prentice Hall, New Jersey), pp 326-342

Koopman MG, Koomen GC, van Acker BA and Arisz L, 1991. Circadian rhythms in glomerular filtration rate and effective renal plasma flow (ERPF) in patients with nephrotic syndrome.
Kidney Int, 42: 649-656

Luke DR, Wasan KM and Vadiei K, 1990. Lack of circadian variation in renal function in the obese rat: influence of continuous food and water intake. Prog Clin Biol Res, 341(A): 131-136

MacHugh DE and Bradley DG, 2001. Livestock genetic origins: goats buck the trend. Proc Natl Acad Sci USA, 98(10): 5382-5384, doi: 10.1073/ pnas. 111163198

Madan J, Sindhu S and Rose MK, 2020. Changes in plasma biochemical parameters and hormones during transition period in Beetal goats carrying single and twin fetus. Vet World, 13(6): 10251029, doi: 10.14202/vetworld.2020.1025-1029

Markowitz ME, Rosen JF and Mizruchi M, 1985. Circadian variations in serum zinc $(\mathrm{Zn})$ concentrations: correlation with blood ionized calcium, serum total calcium and phosphate in humans. Am J Clin Nutr, 41(4): 689-696, doi: 10.1093/ajcn/41.4.689

Mohammadpour H, Pourjafar M, Badiei K, Oryan A, Keshavarzi B et al., 2017. Seasonal variations of tissues and serum copper concentrations in chronic copper poisoned goats. Iran J Vet Med, 2(2): 41-57, doi: 10.22055/ijrhr.2019. 29498.1024

Mohammed A, Khan A, Pargass I, Bridgemohan P, Edwards AE et al., 2017. Serum mineral levels in goats of various physiological stages in the dry and wet seasons in central Trinidad. J Trace Elem Med Biol, 18(2): 17-27, doi: 10.19112/ 2413-6174-2017-18-2-17-27

Nikolaeva S, Pradervand S, Centeno G, Zavadova V, Tokonami N et al., 2012. The circadian clock modulates renal sodium handling. J Am Soc Nephrol, 23(6): 1019-1026, doi: 10.1681/ ASN.2011080842

Rekib A, 1998. Grazing resources and livestock productivity with special reference to goat production. Indian J Anim Sci, 68: 846-848

SAS, 2001. Statistical Analysis Systems Institute, version 8.2. SAS Institute Inc., Cary, USA

Schmidt ST, Ditting T, Deutsch B, Schutte R, Friedrich S et al., 2015. Circadian rhythm and day to day variability of serum potassium concentration: A pilot study. J Nephrol, 28(2): 165-172, doi: 10.1007/s40620-014-0115-7

Singh P, Dixit VP, Singh B and Gerogie GC, 2001. Plasma aldosterone and major circulatory and urinary electrolytes in buffalo calves as affected by peak summer and winter stress. Int $\mathbf{J}$ Anim Sci, 16(1): 161-166 
Sivakumar AVN, Singh G and Varshney VP, 2010. Antioxidants supplementation on acid base balance during heat stress in goats. AsianAustralas J Anim Sci, 23: 1462-1468, doi: 10.5713/ajas.2010.90471

Solocinski K and Gumz ML, 2015. The circadian clock in the regulation of renal rhythms. J Biol Rhythms, 30(6): 470-486, doi: 10.1177/ 0748730415610879
Yokoyama K, Araki S, Sato H and Aono H, 2000. Circadian rhythms of seven heavy metals in plasma, erythrocytes and urine in men: observation in metal workers. Ind Health, 38: 205-212, doi: 10.2486/indhealth.38.205

Zhang D and Pollock DM, 2020. Diurnal regulation of renal electrolyte excretion: the role of paracrine factors. Annu Rev Physiol, 82: 343-363, doi: 10.1146/annurev-physiol-021119-034446

Received - 27.03.2021, Accepted - 13.05.2021, Published-01.06.2021

Section Editor: Prof. S. N. Joardar, Associate Editor 